\title{
PUBLIC OBLIGATIONS OF PRIVATE CORPORATIONS
}

\author{
DaVID S. RUDER $\dagger$
}

In his Economic Message to Congress on February 9, 1965, President Johnson requested that any wage increase be a "noninflationary" increase of less than 3.2 percent. $^{1}$ The business community's failure to react violently to this attempt by the federal government to influence business policy reflects a dramatic and fundamental change in the outlook of business leaders during the past thirty years. Although some businessmen still cling to the notion that the business of the corporation is solely to make profits, their position is not a popular one. ${ }^{2}$ One author has stated:

The fact is, the profit motive is simply not fashionable today among emancipated conferees of the Committee for Economic Development or even in the National Association of Manufacturers. It has been dying a lingering, unmourned death for ten years. Rarely can a big business leader eulogize it today without being snubbed by his self-consciously frowning peers. ${ }^{3}$

Most of the debate over the proper role of the private corporation has been in terms of political and economic analysis. Since the chief

$\dagger$ Associate Dean and Professor of Law, Northwestern University. B.A. Williams College, 1951 ; LL.B. University of Wisconsin, 1957.

1 N.Y. Times, Jan. 29,1965 , p. 12 , cols. $3-4,8$.

2 The debate over the corporation's role in society may have begun in its modern form with an article published by Professor Adolf A. Berle in 1931. Berle, The Organization of the Law of Corporate Finance, 9 TENN. L. REv. 125 (1931). Since then, Professor Berle has written four books and numerous articles on the general subject of the corporate role and has engaged in written debate with two authors. His books are: Berle \& Means, The Modern Corporation and PrTvate Property (1932) ; Berle, The 20th Century Capitalist Revolution (1954); Berle, Power Without Property (1959); BerLe, The American Economic REpublic (1963). Debate with Professor E. Merrick Dodd, Jr.: Berle, Corporate Powers as Powers int Trust, 44 HARv. L. REV. 1049 (1931); reply-Dodd, For Whom Are Corporate Managers Trustees?, 45 HARV. L. REv. 1145 (1932); rejoinder-Berle, For Whom Corporate Managers Are Trustees: A Note, 45 HARv. L. Rev. 1365 (1932). Debate with Associate Professor Henry G. Manne: Manne, Current Viezes on the "Modern Corporationt," 38 U. DET. L.J. 559 (1961); Manne, The "Higher Criticism" of the Modern Corporation, 62 ColuMr. L. REv. 399 (1962); reply-Berle, Modern Functions of the Corporate System, 62 CoLUM. L. REv. 433 (1962); rejoinder-Manne, Corporate Responsibility, Business Motivation, and Reality," 343 Annals 55 (1962).

Other works of interest in this field include the following: DRUCKER, THE CoNCEPT OF THE CoRPoration (1964); IIVINGSTON, THE AMIERICAN STOCKHOLDER (1958); Mason, The Corporation in Modern Society (1960); Douglas, Directors Who Do Not Direct, 47 HARv. L. REv. 1305 (1934); Levitt, The Dangers of Social Responsibility, Harv. Bus. Rev., Sept.-Oct. 1958, p. 41.

3 Levitt, supra note 2 , at 43. 
concern in analyzing corporate performance has been public welfare, the questions have often related to the effect of corporate activities upon the economic system and upon the political organization of the state. ${ }^{4}$ The corporate lawyer, however, may have a different focus. Charged with counseling corporate management, he must be concerned with the traditional and still enforceable legal duties owed by corporate managers to the corporation and its owners. His clients are faced with a dilemma articulated by an executive of the General Electric Company:

If you will pardon me for being personal, it makes a great difference in my attitude toward my job as an executive officer of the General Electric Company whether I am a trustee of the institution or an attorney for the investor. If I am a trustee, who are the beneficiaries of the trust? To whom do I owe my obligations? ${ }^{5}$

The following inquiries may be helpful in finding a solution to this dilemma:

1. What are the differences between public and private corporate obligations?

2. To what extent do public and private obligations conflict?

3. What liability will be incurred by a corporate manager who pursues public obligations?

The purpose of this article is to analyze these questions with regard to private corporations. ${ }^{6}$ The analysis will be applicable to small corporations as well as to that group of corporations generally acknowledged to have public obligations by virtue of their size. Although a large percentage of American business is conducted by relatively few corporations, ${ }^{7}$ all have the power to act in the public

4 E.g., Berie, The Economic Republic 100 (1963).

5 Dodd, For Whom Are Corporate Managers Trustees?, 45 HARv. L. REv. 1145, 1153 (1932).

6 Assistance provided by the Russell Sage Foundation under a grant to Northwestern University to promote training and research in law and social science is gratefully acknowledged. The subject matter of this paper extends beyond legal analysis into areas of political science and economics. Berle describes the general subject matter as "that academic no-man's-land where economics, political science, and law must be drawn on to account for present phenomena and if guidance is desired, to guide future developments." Berle, Modern Functions of the Corporate System, 62 Coluar. L. Rev. 433, 436 (1962).

7 See Berle \& Means, The Modern Corporation and Private Property 18 (1932); Kaysen, The Corporation: How Much Power? What Scope?, in MAson, The CoRporation IN MODERN SOCIETY 85-88 (1960). Fortune magazine's annual list of the largest United States corporations provides impressive statistics regarding size. E.g., Fortune, July 1965, pp. 149-68. In 1962 Berle reported that: "135 corporations control about forty-seven per cent of American industrial production now, as they did in 1932. A fair estimate would be that 600 large corporations control between twothirds and three-fourths of that production today . Berle, Modern Functions of the Corporate System, 62 Colum. L. REv. 433, $434^{\circ}$ (1962). 
interest. ${ }^{8}$ Even if not great in national terms, the smaller corporation may have extensive power within a very small community or other relatively limited sphere of activity.

\section{The Public Obligation}

There are many desirable uses to which management might devote corporate resources as part of the corporation's obligation to various segments of the public (including its employees ${ }^{9}$ and the community at large). For example, corporate contributions are often essential to the very existence of local charities. Similarly, corporate contributions have been extremely important in the creation of a workable system of privately endowed colleges and universities. Corporate decisions to enter or remain in a community are sometimes made with the community's employment needs in mind, and therefore become public welfare decisions. On a larger scale, decisions to settle a strike, to avoid inflationary wage or price increases, or to invest in the United States instead of abroad may be made with public policy interests in mind. ${ }^{10}$ Assuming that reasonable corporate activities in satisfaction of public obligations will and should continue, it is nevertheless important to understand the proper rationale for such activities.

As long ago as 1932, Harvard Professor E. Merrick Dodd, Jr. examined the proposition that corporate managers "should concern themselves with the interests of employees, consumers, and the general public, as well as of the stockholders ...."11 He concluded that if

8 A careful distinction should be drawn between size and the separation of ownership from control. A corporation may have public obligations merely because of its large size. It may also be a publicly held corporation by reason of the distribution of ownership of its stock and thought to owe some public obligations for this reason. Although large size and public ownership most often exist together, it is possible for a publicly held corporation to be small in size or for a closely held corporation to be large.

${ }^{9}$ Some writers assert that the corporation owes an obligation to other groups connected with it, specifically to the corporation's employees. But, insofar as the corporation acts to give its employees benefits which are unrelated to profit maximization, the goal undertaken becomes public rather than private. Use of corporate resources to improve working conditions, to increase employees' salaries and to accomplish other improvements in employment conditions, if unrelated to the corporation's profit motives, fall within the public obligation area. On the other hand, the existence of pressures brought by the employees themselves, in the form of labor organization, helps to advance the theory which will be asserted here, that most activities by business corporations which might be open to attack as activities designed merely to satisfy public obligations are supportable upon normal profit maximization theories.

10 A list of possible objects of corporate charity appears in Eells, The Rationale of Corporate Philanthropy, 23 VITAL SPEECHES 216, 220 (1957):

[A] 11 the areas of meaningful human activity apart from public government: the family; the local community; indigenous welfare groups; private schools, colleges, and universities; associations of scholars, scientists, writers and artists; indeed, the whole spectrum of voluntary associations through which men hope in their own ways to achieve their goals.

11 Dodd, For Whom Are Corporate Managers Trustees?, 45 HARv, L. REv. 1145, 1156 (1932). 
the corporate manager can be thought to owe his obligation to the corporate institution rather than to the stockholder-owners, ${ }^{12}$ he may then employ corporate funds "in a manner appropriate to a person practising a profession and imbued with a sense of social responsibility without thereby being guilty of a breach of trust." ${ }^{13}$ Professor Dodd's analysis rested on the concept that the corporation is an institution separate from its existence as a vehicle for the business interests of its shareholders. Professor Dodd noted that such a concept was reflected among businessmen. He stated:

[T] here is in fact a growing feeling not only that business has responsibilities to the community but that our corporate managers who control business should voluntarily and without waiting for legal compulsion manage it in such a way to fulfill those responsibilities. ${ }^{14}$

Such a feeling persists today. Nevertheless, despite years of public acceptance, there remains the significant question whether the underlying premise of Dodd's public obligation theory is acceptable. Written during a time of economic depression, Professor Dodd's analysis rested in part upon "contemporary discussion of the need for a planned economic order . . ." 15 and reached the conclusion that pursuit of public obligations required acceptance of the view that the managers are "guardians of all the interests which the corporation affects and not merely servants of its absentee owners." 16 He stated: "The question . . . is not whether the voluntary acceptance of social responsibility by corporate managers is workable, but whether experiments in that direction run counter to fundamental principles of the law of business corporations." 17 By treating the fiduciary obligations of managers as owed to the institution rather than to its shareholders, Professor Dodd arrived at the conclusion that it would be proper for corporate managers to devote the corporation's resources to the welfare of its employees and of the community rather than to the stockholders. ${ }^{18}$

This article will attempt to demonstrate that contrary to the theory expressed by Professor Dodd, the concept that the corporation is a public institution is not necessary in order to justify most publicly motivated corporate acts. Pursuit of public obligations is

$12 I d$. at 1160.

$13 \mathrm{Id}$. at 1161.

$14 I d$. at $1153-54$.

$15 \mathrm{Id}$. at 1152 .

$16 \mathrm{Id}$. at 1157.

17 Id. at 1162 .

$18 \mathrm{Id}$. at 1163 . 
not inconsistent with the "old" view that the fiduciary obligations of managers are owed to the shareholders. ${ }^{19}$ Given the proper approach, public obligations of private corporations may be satisfied by a corporation without management fear of liability for breach of fiduciary obligations, provided that the managers make full disclosure of their intended and actual use of corporate power and assets to satisfy public obligations.

\section{The Private Obligation: Profit Maximization}

The businessman who incorporates a small business or who incorporates to promote a large business does so with an expectation of making a profit. Although existence of the profit motive is elementary to any business, it must be explicitly recognized in order that a useful comparison with the public interest may be made.

Rejection of the profit motive as the guiding principle for corporate behavior ${ }^{20}$ and substitution of the public interest ${ }^{21}$ carries significant and extensive legal consequences. The traditional legal notion that the corporate manager owes fiduciary obligations to the shareholder-owners of the corporation is based on profit maximization. Historically, the shareholder-owner has had the power by means of a set of well developed legal rules to force the corporate manager to account to him for the use of his property. Corporate power exercised

19 Two decades after his debate with Professor Dodd regarding the proper role of the corporate "trustee," Professor Berle acknowledged his acceptance of Professor Dodd's theses, stating:

Twenty years ago, the writer had a controversy with the late Professor E.

Merrick Dodd, of Harvard Law School, the writer holding that corporate powers were powers in trust for shareholders while Professor Dodd argued that these powers were held in trust for the entire community. The argument has been settled (at least for the time being) squarely in favor of Professor Dodd's contention.

Berde, The 20tr Century Capitalist Revolution 169 (1954).

20 Interestingly, one good statement of the proposition is Berle's: "[A]11 powers granted to a corporation or to the management of a corporation, or to any group within the corporation, whether, derived from statute or charter or both, are necessarily and at all times exercisable only for the ratable benefit of all the shareholders as their interest appears." Berle, Corporate Powers as Powers in Trust, 44 Harv. I. REv. 1049 (1931), reprinted in BerLe \& Means, The Modern Corporation aNd Private Property 248 (1933). As noted above, Professor Berle's position has changed. See note 19 sispra. See also Berle, Modern Fanctions of the Corporate System, 62 CoLuar. L. REv. 433, 442-44 (1962).

21 Drucker states the status of the corporation as follows:

"Big business" . . is "private" and accepted as such-in the sense in which a big university is "private." It is not government-run, but autonomous and under its own rules, pursuing goals set by itself. But it is not a "private affair" and the concern only of its stockholders, executives, and employees. It is an autonomous institution-but a community asset and "public" in its conduct, in its mores, and its impacts.

Drucker, Big Business and the National Purpose, Harv. Bus. Rev., March-April 1962, p. 48, at 59; see Iatham, The Commonzealth of the Corporation, 55 Nw. U.L. REv. $25(1960)$. 
in the pursuit of profit for the benefit of shareholders has been subject to the control established through these developed legal rules. If the underlying profit theory upon which these rules of control are based is discarded, however, it is inevitable that a new set of rules will be established which will be designed to control the exercise of corporate power in the pursuit of public obligations. Consideration of whether society wishes to discard an entire system of controls based upon profit maximization for business must be accompanied by consideration of what the new control rules will contain.

The normal expectation that the corporation is operated for the purpose of making profit is supported by modern economic theory. Economic analysis has long proceeded upon the proposition that businesses operate for the purpose of maximizing profits, although most often over the long rather than the short run period. ${ }^{22}$ According to current economic theory such profit maximization within a competitive context is of benefit to society. ${ }^{23}$ Not only does the pursuit of profit encourage businesses to produce as efficiently as possible, but given mobility of resources and ease of entry into industry, profit maximization encourages allocation of resources in accordance with the demands of the public. ${ }^{24}$ Government encouragement of competition, profit seeking and profit maximization is convincingly reflected in vigorous enforcement of laws designed to prevent the growth of monopoly and oligopoly power and to encourage price competition. Thus not only does economic theory assume that corporations exist to make profit, but a large body of publicly supported law proceeds upon

22 "Businessmen produce for profit." SAmuelson, Economics 384 (6th ed. 1964). Samuelson's analysis of cost and supply rests upon "best profit" concepts. Id. at 444-71. He recognizes as well that "it is probably good business to take the long view and not concentrate on purely immediate gains. Many acts of altruism and apparent generosity can be amply defended in terms of public relations and the maximization of long run profits." Id. at 489.

23 Samuelson notes that the "pursuit of profit and avoidance of loss furnish the motive force behind the whole competitive process ...."Id. at 617. The impact of current business mystique that maximization of profits may be bad is revealed by the following report:

Any sampling of public opinion shows some hostility toward profit. A scientist recently asked a random sample of businessmen if they "tried to maximize their profit." To a man, they all denied this firmly, perhaps because they pictured a profit maximizer as some kind of chiseling extortionist or miser.

Id. at 607-08.

Rostow, To Whom and for What Ends Is Corporate Managenent Responsible?, in MAson, The Corporation IN MODERN Soctety 46, 63 (1960): "[T] he quest for maximum revenue in a competitive market leads to a system of prices, and an allocation of resources and rewards, superior to any alternative, in its contributions to the economic welfare of the community as a whole."

See also Katz, Responsibility and the Modern Corporation, 3 J.L. \& Economrrcs $75,80-82$ (1960).

24 That is, assuming conditions sufficient to fulfill the economist's model of "perfect competition." See SAMUELson, Economics 444-71 (6th ed. 1964). 
the proposition that the competitive pursuit of profit is desirable for the economy. ${ }^{25}$

\section{Conflict Between Public and Private Obligations}

The possibility of conflict between activity designed to benefit society (the public obligation) and activity directed toward profit maximization (the private obligation) is evident. Of course, an activity normally thought to satisfy a public obligation may be justified on the ground that it also fulfills the performance of a private obligation. However, if the activity contributes in no way to profit maximization, a conflict exists. The individual obligated to manage the corporation must do so loyally and with care. ${ }^{26}$ If he acts in the public interest and not for his own benefit, his activity is not proscribed by theories relating to conflict of interest and breach of his duty of loyalty. ${ }^{27}$ The relevant inquiry becomes whether he violates his duty of care when he devotes resources of the corporation to nonprofit activities.

Analysis of existing cases regarding the corporate manager's duty of care makes it clear that the likelihood of liability for mismanagement of a business corporation is slight. A director will be subject to liability for mismanagement only when it is established that he has been negligent or neglectful in his duties, that the damage incurred is causally related to his lack of care or diligence, and that the damage is measurable. ${ }^{28}$ The officer or director who has been diligent is protected by various standards which make it difficult to impose liability. ${ }^{29}$

$25 \mathrm{An}$ aspect of the debate over the antitrust cases appeared recently in Fortune magazine in which one view was that:

We have inherited a marvelously responsive and intricate mechanism, the free market, which we do not understand or appreciate, and so, like savages left a tractor, we poke and rip at it, hit it with clubs and mutter incantations, all in the vain hope of improving its performance. The courts and the legislature preside like a body of medicine men, giving the tribe a new set of chants and directing that yet another piston rod be ripped out or spark plug smashed in order to make the mysterious mechanism behave. This pattern of behavior will take a long time to correct. An educational process of such magnitude is necessarily slow, particularly when there are strong know-nothing forces in the society who will vehemently oppose and vilify the ideas themselves.

Bork \& Bowman, The Crisis in Antitrust, Fortune, Dec. 1963, p. 138, 201; reply -Blake \& Jones, In Defense of Antitrist, Fortune, Aug. 1964, p. 135.

${ }^{26}$ E.g., BAKER \& CARY, CASES on CoRporatrons 403-32 (duty of care), 432-553 (duty of loyalty) (3d ed. 1959).

27 The normal statement of the question regarding duty of loyalty assumes a situation where "the director's fiduciary duty to the corporation makes it improper for him to engage in the transaction or improper for him to derive a personal advantage." Id. at 432 .

$28 I d$. at $403-32$.

29 In Hun v. Cary, 82 N.Y. 65, 37 Am. Rep. 546 (1880), an early leading case, the standard to be met by directors of a bank was set forth as "the same degree of care and prudence that men prompted by self-interest generally exercise in their own affairs." Id. at 71, $37 \mathrm{Am}$. Rep. at 548. 
Ballantine suggests a so-called "prudent director" test, which apparently is accepted in the majority of jurisdictions. ${ }^{30}$ Another test of negligence, the "business judgment rule," is stated in terms of managerial discretion in business affairs. Although the proposition is not always articulated clearly, it seems apparent that the business judgment rule differs little from the prudent director test and will be available to protect officers or directors who have used good faith in managing the corporation. ${ }^{31}$

A recent statement of the business judgment rule may be found in Poirier $v$. Welch ${ }^{32}$ in which the court was concerned with a complaint that the appointed board of directors of Communications Satellite Corporation had decided to select six of its number as candidates for re-election. The court stated:

In any event, in the absence of any proof to the contrary, and there is none here, the question was solely a matter of business judgment on the part of the present Board of Directors, which is not subject to judicial review. This Court may not substitute itself for the Board in determining matters of internal management of the corporation, unless there is some violation of law or fraud. ${ }^{33}$

Both the "business judgment rule" and the "prudent director test" are significant barriers to the imposition of liability on a director who has acted in satisfaction of what he conceives to be a public obligation. To invoke the protection of either rule, a director need only demonstrate that the activity in which the corporation is engaged can be justified as short term or long term profit maximization.

Underlying this defense as it relates to public obligations is the hypothesis that the relationship between activity normally considered to be in the public interest and profit maximization must be a reasonable one. This hypothesis in turn assumes that the business judgment rule uses profit maximization as its standard. Additionally, profit maximization need not be short term, but can take place over a long period of time. Over the long term, activity designed to satisfy public obligations will in many cases be consistent with the welfare of the corporation and its profits. These assertions imply that the nature of the corporation has not changed, that activities solely in the public interest are inconsistent with corporate welfare, and that therefore such

30 "The just rule is that the directors undertake to use such care and diligence and give such time and attention as ordinarily careful and prudent men could reasonably be expected to exercise on behalf of such a corporation under similar circumstances." Ballantine, CoRporatrons 158 (rev. ed. 1946).

31 Id. at 161.

32233 F. Supp. 436 (D.D.C. 1964).

33 Id. at 439. 
activities will not be protected by the business judgment rule. Indeed, if the concept that the stockholder is the owner of the corporation is discarded, ${ }^{34}$ it is inevitable that new standards will be created by which to judge corporate action directed to the public interest. As Professor Adolf A. Berle has observed, no power absolute in terms is absolute in fact..$^{35}$ The power of managers to act in the public interest without any regard to corporate interest must be subject to "essential equitable limitations." ${ }^{36}$ It is doubtful whether such limitations when applied to corporate actions in the public interest would have the same flexibility and generosity now associated with the business judgment rule.

\section{A. The Public Obligation and Long Run Profit Maximization}

The concern expressed above will be unimportant if it can be demonstrated that all corporate activity nominally devoted to public goals can be justified in terms of long term profit maximization. Certainly most corporate activity is so related to profit maximization that it falls within the business judgment category.

Activity clearly within the "public obligation" category can be classified in the following ways:

\section{Conformance With Legislative Standards}

Much corporate activity is in response to standards dictated by the public policy of federal and state statutes. For example, corporations which refrain from entering into collusive pricing agreements can be characterized as pursuing the public objectives of the Sherman Act. Similarly, all business activity designed to conform to federal or state regulation can be described as profit maximizing activity, since violation of the law may lead to substantial fines and penalties. For example, as a result of government and private Sherman Act suits against General Electric, ${ }^{37}$ that company reported that its nine month earnings for 1964 had been reduced from 203,980,000 dollars to $153,199,000$ dollars

34 Cf. Manning, Book Review, 67 YALE L.J. 1477, 1490-91 (1958). (1931).

35 See Berle, Corporate Powers as Powers in Trust, 44 Harv. L. Rev. 1049, 1073

36 Ibid. Examination of articles written on subjects in which the public obligation question is not conceived to be at issue reveals how thoroughly entrenched is the concept that the duty of corporate managers is toward the corporation and its owners rather than the public. E.g., Bayne, $A$ Philosophy of Corporate Control, 112 U. PA. L. REv. 22, 32-33 (1963), which suggests that "the exclusive benefit of all activity within the scope of custody belongs to the entity," id. at 35, and that "the overriding objective of the corporate entity is its own common good, which is, generally, to make profits." Id. at 42. Analyzing liability for sale of a controlling corporate interest, Bayne finds an apparent identity between the shareholders and the corporation, stating: "To say that the so-called premium belongs to all the shareholders is to say that the premium belongs to the corporation." Id. at 65 .

37 Sherman Act § 8, 26 Stat. 209 (1890), 15 U.S.C. §7 (1964). 
due to settlements involving only the year $1960 .^{38}$ Such losses lend practical support to a refusal to engage in activity which might otherwise maximize profits in the short run. Thus, compliance with legislative standards, a public obligation, may be motivated and justified by profit maximization concepts.

\section{Community Welfare Activity}

Modern day corporations engage in a number of activities which many years ago would not have been thought to be business related. Such activities qualify as public obligations by virtue of their relationship to the needs of the community. The clearest example of such activity is the charitable contribution sanctioned in most jurisdictions by statute. ${ }^{39}$ The Model Business Corporation Act contains the following provision:

\section{Section 4. GENERAL POWERS}

Each corporation shall have power: . . . (m) To make donations for the public welfare or for charitable, scientific or educational purposes; and in time of war to make donations in aid of war activities. ${ }^{40}$

It might be asserted that the power to make charitable contributions gives a corporate board of directors power to make donations for whatever purposes and in whatever quantity it wishes. As a practical matter the amount of contributions which a corporation will make is probably limited by the Internal Revenue Code provision limiting the deductibility of corporate contributions to five percent of the corporation's net earnings for each year. ${ }^{41}$ Conceivably, however, a board of directors motivated by a desire to satisfy public obligations could use corporate funds in excess of that limitation to promote a desired charitable end. A shareholder might counter with an action against the directors claiming that the contributions in excess of the five percent limitation were a waste of corporate assets for which the directors should be liable. Such an attack could be met by a defense based upon the business judgment rule. In the case of a contribution to an educational institution, for example, the argument could be that the contributions were reasonably related to corporate needs such as: corporate interest in creating a public image; the necessity for developing educated individuals within the community who would ulti-

38 Wall Street J., Oct. 12, 1964, p. 22, col. 1.

39 All but a few states have statutory provisions authorizing donations. See the list of statutes in ABA-ALI MODET BUS. CORP. ACr ANN. \$4(m) (1960).

40 Ibid.

41 INT. Rev. Code of 1954, §170(b) (2). 
mately be willing and anxious to be employed in that community; or the necessity for developing special talents which would ultimately be useful to the corporation. These arguments would be easier for the corporation and its directors if the charitable contributions were reasonably related to the corporation's general size, its net annual earnings, its capital, and its place in the community.

Justification of this type appears in the Report of the 79th Annual Meeting of Standard Oil Company (New Jersey) ${ }^{42}$ reporting a shareholder's proposal to amend the corporation's by-laws so that no corporate funds could be given to any charitable, educational, or similar organization except for purposes in direct furtherance of the business interests of the corporation. The argument of the shareholder was that: "Your Directors are giving millions of dollars of your corporation's money to charity. This seems wrong. Your company is supposedly run solely for the stockholders' benefit. It is not an eleemosynary institution." 43 The company opposed the resolution. Its president, Mr. M. J. Rathbone, stated:

We in the Jersey Company believe in being good corporate citizens. We think the principle of corporate giving is well established. It is encouraged by our tax laws; it has been upheld in our courts; and the public has come to expect it of corporations. Perhaps this was not so, say, some twentyfive years ago, but it is today. In our judgment these contributions are extremely important if Jersey is to merit the good will of the public, which is essential to the prosperity of your company. ${ }^{44}$

The position taken by the management of Standard Oil that charitable activity would redound to the benefit of the corporation conforms with the business judgment standard.

\section{Response to Government Pressure}

An additional area of business activity which can be justified according to business judgment concepts is corporate action taken either because the government is bringing indirect pressure upon the corporation or because pressure might be used by the government.

Large corporations ${ }^{45}$ are particularly vulnerable to governmental pressure because of the continual threat of legisiation aimed at reducing

42 Report of the 79th Annual Meeting, Standard Oil Company (New Jersey), May 24, 1961.

43 Statement of Mr. Watson Washburn, representing Mrs. Alice V. Gordon. Id. at 15 . Ibid.

44 Statement of Mr. M. J. Rathbone, President of the Standard Oil Company.

45 Analysis in terms of large corporations does not mean the principles set forth are inapplicable to small corporations. 
their size or controlling them. ${ }^{46}$ The pressure which President John F. Kennedy used on the steel industry provides an excellent illustration of nonlegislative government power which is available. ${ }^{47}$ On April 10, 1962, several steel companies announced a general increase in prices which President Kennedy had opposed as inflationary. After seventy-two hours of intense pressure by the Administration, the industry rescinded its price increase. ${ }^{48}$ Government actions during this period included: the President's statement at a news conference that the price increase was unjustified; an expression of concern by Senator Kefauver, Chairman of the Senate Antitrust Subcommittee; threats by Senator Kefauver and the Justice Department to investigate the price increase; suggestions for legislation empowering the courts to prohibit price increases in basic industries such as steel until there had been a "cooling off period"; calls by Administration officials to representatives of certain steel companies which had not yet joined in the price increase requesting that they refrain from raising prices; and authorization for FBI investigation of a statement by the president of Bethlehem Steel that he had objected to the price increase. ${ }^{49}$ The New York Times summarized the first twenty-four hours of activity as follows:

Thus by nightfall on Wednesday . . . the administration was pressing forward on four lines of action: First, the rallying of public opinion behind the President and against the companies. Second, divide-and-conquer operation within the steel industry. Third, antitrust pressure from the Justice Department, the Federal Trade Commission, the Senate and the House. Fourth, the mobilization of friendly forces within the business world to put additional pressure on the companies. ${ }^{50}$

Subsequently, Secretary of Defense MacNamara indicated that the Defense Department had ordered defense contractors to shift purchases to companies that had not raised prices. Still later, the Defense

46 Berle presents an "incomplete list of the areas of American economy presently controlled . . " Berle, THE 20th Century Capitalist Revolution 49 (1954). He discusses the force of public opinion and the fear of government action in severai of his works. BERLE, POWER WITHOUT PROPERTY 92 (1959) ("In American society, the ultimate limitation on economic power is the possibility of energizing, in any one of various ways, the political power of the government."); BERLE, THE 20TH Century Capitatist Revolution 54 (1954); Berle, Modern Functions of the Corporate System, 62 Colum. L. REv. 433, 443 (1962).

${ }^{47}$ See Carroll, Steel: A 72-Hour Drama With an All-Star Cast, N.Y. Times, April 23, 1962, p. 1, col. 4 .

48 Ibid.

$49 I d$. at 25 , cols. $1-8$.

60 Id. at 25 , col. 5 . 
Department actually awarded a contract for more than five million dollars worth of a special armor plate to the Lukens Steel Company, which had not raised prices. ${ }^{51}$

When government pressure is brought to bear on a business corporation in this way, the directors of the corporation can readily argue that the resulting reaction is justified under the business judgment rule even though not responsive to specific legislation. Failure to accede to such pressure would invite serious reprisals for business, either through administrative activity or through future legislation..$^{52}$

\section{B. Public Obligations Unrelated to Corporate Welfare}

Three categories of business activity fulfilling public obligations have been examined: activity carried on in conformity with legislative standards, activity carried on in response to government pressure, and activity carried on in pursuit of community welfare needs which also benefits the corporation. All of the activity discussed thus far can be justified as being in the best interests of the corporation upon business judgment standards.

Arguably there is another area of business activity in which public obligations are fulfilled-activity which is unrelated to the welfare of the corporation. ${ }^{53}$ In $A$. P. Smith $M f g$. Co. v. Barlow, ${ }^{54}$ a New Jersey decision, a group of shareholders challenged a corporate donation of 1,500 dollars to Princeton University. Despite the existence of a resolution by the board of directors that the contribution was in the corporation's best interest, thus invoking the business judgment rule, the court embraced a larger proposition that, "modern conditions require that corporations acknowledge and discharge social as well as private responsibilities as members of the communities within which they operate." ${ }^{55}$ Although the court had previously recognized the common-law rule that "those who managed the corporation could not disburse any corporate funds for philanthropic or other worthy public cause unless the expenditure would benefit the corporation," ${ }^{56}$ it chose to advance that rule only as an alternative method of upholding the donation. ${ }^{57}$ The New Jersey view might be broadly construed to support the proposition that corporate managers have power to make charitable contributions or to take other steps to satisfy public obliga-

51 Id. at 25 , col. 8 .

52 See text accompanying notes $36-37$ supra.

53 See text accompanying notes 12-13 supra.

5413 N.J. 145,98 A.2d 581 (1953).

55 Id. at 154, 98 A.2d at 590 . The court cited Dodd, For Whom Are Corporate Managers Trustees?, 45 HARV. L. REv. 1145 (1932), 13 N.J. at 149, 98 A.2d at 584, and Berte \& Means, The Modern Corporation and Private Property (1948), 13 N.J. at 149,98 A.2d at 584.

58 Id. at $149,98 \mathrm{~A}$. $2 \mathrm{~d}$ at 584 .

57 Id. at 154,98 A.2d at 590 . 
tions without regard to the benefit which may accrue to the corporation. Although such an interpretation of the corporate role is arguable, it is not necessary and should not be followed. ${ }^{58}$

One assumption underlying the pure public obligation theory has been suggested by Professor Berle who asserts it is incorrect to assume that "as a matter of course men would always act according to their calculation of personal profit or advantage." $50 \mathrm{He}$ is disturbed by the proposition that activities which stem from altruistic motives ${ }^{60}$ must be upheld for business reasons. He states:

The fact is that boards of directors or corporation executives are often faced with situations in which they quite humanly and simply consider that such and such is the decent thing to do and ought to be done. Or if one chooses, that it is a politically expedient thing and ought to be done. They apply the potential profits or public relations tests later on, a sort of left-handed justification in this curious free-market world where an obviously moral or decent or humane action has to be apologized for on the ground that, conceivably, you may somehow make money by it. ${ }^{\text {B1 }}$

Despite Professor Berle's concern, the better view is that when a trustee is dealing with property that belongs to another, he must justify his altruistic action on a business basis. Since most actions can be so justified, ${ }^{62}$ the traditional profit maximization theory yields a result consistent with corporate satisfaction of public obligations. No good reason remains for discarding the existing guidelines to managerial responsibility. ${ }^{\text {. }}$

58 Prunty, Love and the Business Corporation, 46 VA. L. Rev. 467, 471-72 (1960), concludes that all of the charitable gift cases can be reconciled with the common-law rule of Hutton v. West Cork Ry., 52 Ch. D. 689,698 (1883), that the activity must be "reasonably incidental to the carrying on of the company's business for the company's benefit." He asserts that the Hutton principle "assumes a business judgment and necessarily excludes a wholly altruistic act." Prunty, supra at 474. The charitable giving cases are thus viewed as involving only an extension of business judgment concepts to recognize that indirect and long run benefits fall within the business judgment category. Ibid.

59 Berle, The American Economic Republic 201 (1963).

60 Referring to the "Protestant ethic," $i d$. at 192, Berle suggests that the great success of the United States economy has been due to what he calls the "Transcendental Margin," defined as "the product of a value system that causes effort and expenditure beyond that calculated as conducive to the personal advantage of an individual or his immediate family group." Id. at 202. (1962).

61 Berle, Modern Functions of the Corporate System, 62 ColuM. L. REv. 433, 444

62 See text accompanying notes 37-52 supra.

63 Katz, Responsibility and the Modern Corporation, 3 J.L. \& Economics 75, 82 (1960), suggests that:

The only statutes or cases which suggest any departure from this [profit maximization] standard are those relating to corporate gifts. They afford no basis for Professor Berle's general assertion that "modern directors are not limited to running business enterprises for maximum profit but are in fact and recognized in law as administrators of a community system." 
The policy advocated here is that reliance upon traditional profit maximization theory does not amount to rejection of modern day notions of corporate responsibility. Within the confines of the business judgment rule there is ample opportunity for expenditure of corporate funds upon worthwhile public welfare measures. The only limitation is that corporate policy must be reasonably related to long term corporate benefit. ${ }^{64}$

This analysis might be tested in relation to the field of civil rights. Currently, the civil rights area suggests possibilities for business activity induced by legislative compulsion, other types of government pressure, or mere desire to satisfy public need. Every corporation must conform to the Civil Rights Act ${ }^{65}$ and in that regard will be performing a public obligation imposed by legislation. Title II requires certain businesses whose operations affect interstate commerce to avoid discrimination ${ }^{66}$ and Title VII requires that corporations and other businesses refrain from discrimination in employment practices. ${ }^{67}$ Thus, activity designed to conform with the standards laid down by the Civil Rights Act falls clearly within the sound business judgment category.

Given the flexibility of the business judgment rule, however, other corporate activity directed toward improving civil rights could probably be justified as contributing to long range profit potential. ${ }^{68}$ For example, it has been suggested that United States Steel should wield its economic power in Birmingham, Alabama, to force businesses there to offer opportunities to Negroes. ${ }^{69}$ If such action should be taken, the

64 Eells, The Role of Corporate Enterprise in Society, 23 VITAI SPEECHES 216, 218 (1957), recognizes the distinction between corporate activities which must be justified "on the balance sheet in the forseeable future" and those which are designed "to strengthen the environmental factors on which the future of the business depends." It is in the latter area that the modern view of the business judgment rule suggested in this article will probably be tested.

65 Civil Rights Act of 1964, §101, 78 Stat. 241 (1964), 42 U.S.C. § 1971 (1964). 6678 Stat. 243 (1964), 42 U.S.C. \$2000a(b) (1964).

6778 Stat. 253 (1964), 42 U.S.C. §2000e (1964).

68 Except, of course, activity which bankrupts the corporation in the short run.

69 [C] ritics ... . have contended that United States Steel, which is the largest employer in Birmingham [Alabama], could ease racial strife there by exerting its economic influence in behalf of improved Negro opportunities in the community.

These critics say that the company could help bring this about by warning the city it did not want its management people to live in a tension-ridden atmosphere, and by making it clear to banks and suppliers that it intended to give more business to those who favored better Negro opportunities.

N.Y. Times, Oct. 30, 1963, p. 1, col. 7. Roger Blough, Chairman of the Board of Directors of United States Steel, replied by letter to the Times, in part, as follows:

I believe that while government-through the proper exercise of its legislative and administrative powers-may seek to compel social reforms, any attempt 
directors could argue that the company would be better off in the long run if racial strife were eliminated and that in the best judgment of the directors the elimination of such strife could be accomplished by use of the corporation's economic power to accomplish that objective. On the other hand, if the view of the New Jersey court in the charitable contribution cases were the law, ${ }^{70}$ the profit maximization justification would not be necessary. United States Steel would be entitled to wield its great power for public welfare purposes solely because it owes a public obligation, ${ }^{71}$ and without any extant system of legal control over the exercise of that power. Although the result may be the same as when the activities are profit justified, a bold public obligation theory raises significant and disturbing difficulties.

\section{Who Selects the Managers?}

If the theory that managers may use the assets of the corporation in order to satisfy public obligations without considering corporate profits is accepted, the role of a public institution is thrust upon the corporation. It then becomes important to know how managers are selected. Despite reforms suggested by advocates of "shareholder democracy," "72 a dissatisfied shareholder in most publicly held corporations is unable to influence the election of a new manager. The control of the proxy machinery is vested in management, and individual votes are too widely dispersed to be effective. The shareholder of such a corporation has in a sense been disenfranchised, since he is unable either to influence or select the management of the corporation. Professor Berle poses the problem as follows:

Change of management by contesting for stockholders' votes is extremely rare, and increasingly difficult and expensive to the point of impossibility. The legal presumption in favor of management, and the natural unwillingness of courts to

by a private organization like U.S. Steel to impose its views, its beliefs and its will upon the community by resorting to economic compulsion or coercion would be repugnant to our American constitutional concepts, and that appropriate steps to correct this abuse of corporate power would be universally demanded by public opinion, by Government and by The New York Times. N.Y. Times, Nov. 7, 1963, p. 36, cols. 5-6.

70 See text accompanying notes 54-58 supra.

71 For an opinion regarding the use of power by United States Steel to solve racial problems see, Hacker, Do Corporations Have a Social Duty?, N.Y. Times, Nov. 17, 1963, \$6 (Magazine), p. 21.

72 Representative works discussing the general problem of shareholder democracy include: Berle \& Means, The Modern Corporation and Private Property (1933); Emerson \& Latcham, Shareholder Democracy (1954); Ltvingston, The AmeriCAN STOCKHOLDER (1958); Rostow, To Whom and for What Ends Is Corporate Management Responsible?, in Mason, THE CoRporation IN MODERN SOCIETY 46 (1960); Manne, The "Higher Criticism" of the Modern Corporation, 62 Colus. I. REv. 399 (1962). 
control or reverse management action save in cases of the more elementary types of dishonesty or fraud, leaves management with substantially absolute power. ${ }^{73}$

Although those discussing shareholder democracy have been primarily concerned with the possible use of corporate power for the self-interest of managers rather than with the use of corporate power in the public interest, some have suggested appointing public representatives to corporate boards. ${ }^{74}$ Such a suggestion indicates the important problem underlying the theory that management may act for the public interest without regard to the corporation's interest. Such a theory contemplates that corporate directors will be empowered to decide matters relating to the public welfare but that they will not be selected by or be responsible to the public. If the corporation acts as a public institution, the corporation should then be controlled by the public. $^{75}$ Professor Berle has recently expressed his confidence in the "instincts and impulses" of the men who are directing corporations. ${ }^{76}$ Such confidence may be merited for the present, but it should not be substituted for a profit theory which protects the corporate welfare should these managers decide to recognize their public obligations in full magnitude. ${ }^{77}$

If corporate managers believe that their only obligation is to maximize profits and that any activities satisfying public obligations must be justified as profit maximizing, the objections just raised will be partially overcome. By pursuing private rather than public ends, corporate managers will nullify the need for their selection by the public. By pursuing profit maximizing activities, the corporate managers will in part overcome the criticism frequently raised by advocates of shareholder democracy that corporate managers are not paying sufficient attention to the obligations owed to the corporate owners.

\section{Is a Pure Public Obligation Theory Necessary?}

When the basis for traditional corporate fiduciary obligation theory is examined, another difficulty in allowing corporate action in

78 Berle, The 20th Century Capitalist Revolution 180 (1954).

74 See the list of solutions in Rostow, To Whom and for What Ends Is Corporate Management Responsible?, in Mason, The Corporation IN Modern Society (1960).

75 This question is already being raised with regard to tax exempt private foundations which have amassed large amounts of property. Sacks, The Role of Philanthropy: An Institutional Viez, 46 VA. L. ReV. 516 (1960).

76 Berle, The 20th Century Capitalist Revolution 186 (1954). See also Berle, The American Economic Republic 43 (1963).

${ }^{77}$ Manne, The "Higher Criticism" of the Modern Corporation, 62 Couvm. L. REv. 399, 415 (1962), does not share Berle's confidence in the skills of management in making welfare decisions. See also Rostow, To Whom and for What Ends Is Corporate Management Responsible?, in MAson, The Corporation IN MoDerN SOCIETY 46, 68 (1960). 
the public interest without regard to corporate benefit becomes apparent-the shareholder will lose his protection against use of corporate assets for nonshareholders. The traditional fiduciary obligation theory insists that a corporate manager owes an obligation of care and loyalty to shareholders. If a public obligation theory unrelated to profit maximization becomes the law, the corporate manager who is not able to act in his own self interest without violating his fiduciary obligation, may nevertheless act in the public interest without violating that obligation. His response to a shareholder suit alleging that he should be liable for devoting the assets of his corporation to a public use might well be as follows:

If the assets of the corporation are devoted to paying dividends to stockholders, and the payment is made equitably, no shareholder objection will be entertained. The dividend payment will not violate any duty of loyalty nor be a waste of corporate assets, since the assets will benefit a group to whom the manager of the corporation owes a fiduciary obligation as trustee. On the other hand, if corporate assets are devoted to the personal interests of the manager, he will violate his trustee's duty of loyalty. If, however, the corporation owes an obligation directly to the public, use of corporate assets for public purposes is not a use devoted to the special interest of the trustee, but is merely a permissible payment for the use of a second group of corporate beneficiaries.

If a corporation owes an obligation to the public which is unrelated to interests of the corporation, then fulfillment of a public obligation will be an adequate defense to any shareholder suit alleging waste of corporate assets, mismanagement of the corporation, or other malfeasance in office. Thus, if the pure corporate obligation theory is adopted, management activities can then be tested against a standard of "public good" unrelated to the well being of the corporation's owners, and the shareholder will have lost part of his ability to make management account to him. If the standard of sound management actions becomes merely that of the public good, limitless "legitimate" uses for corporate funds other than shareholder welfare will be possible. Management might, for example, use corporate funds without limit for objectives such as contributions to scientific and charitable organizations, research activities devoted to public welfare purposes, higher wages and salaries for its employees, lower prices ${ }^{78}$ or a host of other public considerations. 
A pure public obligation theory of corporate management cannot be supported without corollary acceptance of the corporation as a public rather than a private institution. Since it is possible at present for corporate management to pursue most public objectives while at the same time acting in a manner consistent with the corporation's private interest, the erection of a pure public obligation theory is unnecessary. At present shareholder suits alleging misuse of corporate funds in satisfaction of public obligations can be met with business judgment theories consistent with the existence of the private corporation as a private institution. Suggestions such as those advanced by Professor Dodd and others that the professional manager should pursue public objectives without reference to profit maximization can only lead to confusion and difficulty for the corporate manager and for the corporation. In contrast, corporate activity designed to satisfy both public obligations and long range profit maximization is consistent with management fiduciary obligations to stockholders and with the proper private role of the corporation. As Professor Eugene Rostow states:

The responsibility of corporate directors requires redefinition. It may give us a warm and comfortable feeling to say that the director is a trustee for the community, rather than for his stockholders; that he is a semipublic official, or a quasi-public official, or some other kind of hyphenated public officer. It would be more constructive, however, to seek redefinition in another sense: to restate the law of corporate trusteeship in terms which take full account of the social advances of this century, but which direct the directors more sharply to concentrate their efforts on discharging their historic economic duties to their stockholders. ${ }^{79}$

The modern solution may simply be that corporate managers should continue to recognize the traditional role of profit maximization, but that in so doing they should consider as important factors community welfare, legislation and public pressure, all of which will affect the long term profits of the corporation. Nevertheless, any activities of the corporation which cannot be justified in terms of long run profit maximization should be avoided.

\section{The Role of Disclosure}

Although helpful in placing the relationship of the corporate manager to the corporation in the proper perspective, management de-

79 Rostow, To Whom and for What Ends Is Corporate Management Responsible?, in Mason, The Corporation IN MODERN SOCIETy 46, 68-69 (1960). 
votion to long run profit maximization may not be of great help to the corporate shareholder. The shareholder is still faced with the difficulties inherent in bringing a derivative suit or in attempting to initiate a proxy fight. Although recognition of the validity of a profit maximization theory as the core of corporate existence may reduce demands for public representation on boards of directors, the shareholder must still contend with a viable business judgment rule giving the corporate management something close to autonomy in control of the corporation as long as a reasonable relationship to profit motives can be demonstrated.

However, the autonomy need not be complete. Several provisions of the federal securities laws offer protection to shareholders against nondisclosure of material facts. ${ }^{80}$ A measure of protection may be afforded the shareholder if the definition of "material facts" under the federal securities laws is expanded. Since it is probable that in the short run the earnings and dividends of a corporation which recognizes public obligations will not be as great as are those of corporations which do not recognize such obligations, management's decision to forego short run profits will probably be material to the average stockholder. ${ }^{81}$ Thus, a management policy determination to pursue public obligations may become a material fact which must be publicly disclosed. Failure to do so may give rise to liabilities both for the company and for corporate management. ${ }^{82}$

\section{CoNCLUSION}

Undoubtedly the nature of the corporation is no longer what it was during the early development of corporate law. However, the growth of large corporations and the development of the concept that corporations owe public obligations need not herald the abandonment

80 See, e.g., (1) registration provisions in the Securities Act of $1933, \S \S 5,10$, $11,12(1), 48$ Stat. 77, 81, 82, 84 (1933), as amended, 15 U.S.C. $\$ \S 77 e, 77 \mathrm{j}, 77 \mathrm{k}$, $77 l(1)$ (1958), and in the Securities Exchange Act of 1934, $\$ 12,48$ Stat. 892, as amended, 15 U.S.C. $\$ 78 l$ (1958); (2) proxy solicitation requirements in the 1934 act, $\S 14,48$ Stat. 895 , as amended, 15 U.S.C. $\$ 78 \mathrm{n}$ (1958); and (3) general fraud provisions in the 1933 act, $\$ \$ 12(2), 17,48$ Stat. 84 , as amended, 15 U.S.C. $\$ \$ 77 l$, $77 \mathrm{q}$ (1958), and the 1934 act, $\$ \$ 9,10,48$ Stat. $889,891,15$ U.S.C. $\$ \$ 78 \mathrm{i}, 78 \mathrm{j}$ (1958). The broadest protection seems to be under Rule 10b-5 of the Securities and Exchange Commission, 17 C.F.R. $\$ 240.10 \mathrm{~b}-5$ (1964). That rule makes it unlawful to make an untrue statement of 2 material fact or to refrain from disclosing material facts in connection with a purchase or sale of securities.

81 For an interesting recent discussion of materiality under Rule 10b-5, see List v. Fashion Park, Inc., 340 F.2d 457 (2d Cir. 1965).

82 For references regarding Rule 10b-5 see Fleischer, "Federal Corporation Law": An Assessment, 78 HARv. L. Rev. 1146, 1160 (1965) ; Ruder, Civil Liability Under Rule 10b-5: Judicial Revision of Legislative Intent?, 57 Nw. U.L. REv. 627 \& n.2, 687 (1963) ; Ruder, Pitfalls int the Development of a Federal Law of Corporations by Implication Through Rule 10b-5, 59 Nw. U.L. REv. 185 (1964); Comment, 74 Y ALE L.J. 658 (1965). 
of profit maximization. Whether induced by government legislation, government pressure, or merely by enlightened attitudes of the corporation regarding its long range potential as a unit in society, corporate activities carried on in satisfaction of public obligations can be consistent with profit maximization objectives. In contrast, justification of public obligations upon bold concepts of public need without corporate benefit will merely serve to reduce further the owner's influence on his corporation and to create additional demands for public participation in corporate management. Corporate managers will be wise both to disclose their decisions to satisfy public obligations with corporate assets and to justify their decisions on theories of profit maximization. Under such circumstances it is likely that management may use corporate assets to satisfy public obligations without fear of liability. 